\title{
The Talmudic Prisoner's Dilemma
}

Uri Weiss

Follow this and additional works at: https://digitalcommons.tourolaw.edu/lawreview

Part of the Criminal Law Commons, and the Religion Law Commons

\section{Recommended Citation}

Weiss, Uri (2021) "The Talmudic Prisoner's Dilemma," Touro Law Review. Vol. 37: No. 1, Article 13. Available at: https://digitalcommons.tourolaw.edu/lawreview/vol37/iss1/13

This Article is brought to you for free and open access by Digital Commons @ Touro Law Center. It has been accepted for inclusion in Touro Law Review by an authorized editor of Digital Commons @ Touro Law Center. For more information, please contact Iross@tourolaw.edu. 


\title{
The Talmudic Prisoner's Dilemma
}

\author{
Uri Weiss*
}

\begin{abstract}
:
We argue that there is a stream in the Talmud that attributes the responsibility to one player alone in the case of a joint crime/joint tort and even in dividing the credits for a joint Mitzvah. We used the game theory to investigate which incentives are provided by this approach, which games are created, which games are blocked, and to which results this approach leads. In this paper, we present some Talmudic games.

Although in Jewish law, a sinner cannot be a witness, one Talmudic rabbi proposes a rule that, in the case of a joint crime, one of the criminals may testify against a friend (who is the other criminal), but the court will not recognize the self-incriminating part of the testimony. The testimony of the criminal will also neutralize the friend's capacity to testify against the criminal since the friend will be considered a sinner after the initial testimony. We argue that this rule may lead to maximal deterrence.

We also investigate other Talmudic rules that impose responsibility on (only) one partner in the case of a joint deed: the halachic rule, which imposes responsibility in the case of bribery on the taker only. Another Talmudic rule that imposes the responsibility on the last player and only in the case of a joint murder/tort/mitzvah that was performed sequentially and the rule that imposes responsibility (only) on the agent and not on the sender. We also investigate the different rules about imposing responsibility on the partners who did not cover a pit. Surprisingly, there are rules that impose responsibility on only one partner, and we argue that this prevents a prisoner's dilemma.

This paper is a part of the developing field of the Talmud and Game Theory.
\end{abstract}

* Dr. Uri Weiss, a Polonsky Academy Fellow, the Van Leer Jerusalem Institute, and a Visiting Scholar at the Hebrew University of Jerusalem. I would like to thank Robert J. Aumann, Joseph Agassi, Shai Dothan, Benny Porat, Eli Raful, and Omri Yadlin for their useful comments. 


\section{The Talmudic Prisoner's Dilemma}

\section{INTRODUCTION - TALMUD AND GAME THEORY}

\section{A. Academic Writing}

Barry O’Neil, Robert J. Aumann, and some other game theoreticians established the field of game-theoretical analysis of Jewish law. ${ }^{1}$ O'Neil investigated a problem of four sons sharing an inheritance; a problem that was proposed by Rabbi Iben Ezra (1140). ${ }^{2} \mathrm{Au}-$ mann and Maschler found equivalence between a common method of division in Jewish law, the Garment rule, which is a rule of division between two persons, ${ }^{3}$ and a particular division proposed by a rabbi in a particular Mishnah (regarding three persons) that discusses a concrete problem of division. ${ }^{4}$ By this means, Aumann and Maschler used

1 See Barry O'Neill, A Problem of Rights Arbitration from the Talmud, 2 Mathematical Soc. Scis. 345 (1982); Robert J. Aumann \& Michael Maschler, Game Theoretic Analysis of a Bankruptcy Problem from the Talmud, 36 J. ECON. THEORY 195 (1985) [hereinafter Game Theoretic Analysis]; Robert J. Aumann, Risk Aversion in the Talmud, 21 ECON. Theory 233, 235 (2003); Robert J. Aumann, Some Non-Superadditive Games, and Their Shapley Values, in the Talmud, 39 INT'L J. GAME THEORY 3, 3 (2010) [hereinafter Some Non-Superadditive Games].

${ }^{2}$ O'Neill, supra note 1 , at 345.

3 The Garment rule provides the following:

Two [persons appearing before a Court, both] holding a garment [at the fringes of either side of the garment]. One of them says, "I found it," and the other says: "I found it;" one of them says: "It is all mine," . . and the other says: "It is all mine" . . then, one swears that his share in it, is not less than half, and the other swears that his share in it, is not less than half, and should then be divided between them.

Mishnah Bava Metzia 1:1.

${ }^{4} \mathrm{O}$ 'Neil raises the possibility that Iben Ezra's problem of division was inspired by a particular problem of division in a particular Mishna in Kethuboth. The same Mishna in Kethuboth is also discussed by Aumann and Maschler (1985). However, O'Neil suspects that the Iben Ezra was influenced by the Garment rule: "Another possible Talmudic source for Ibn Ezra's problem is a Mishna in the Kethubot, which deals with marriage contracts involving a promise of a sum money to each of a man's brides ... We suspect that Ibn Ezra was inspired by the found garment problem and not marriage contract rule, since the latter division seems to be on different principles than the one he advocates." Aumann and Maschler view the Mishna in Kethuboth as an application of the Garment rule. See Barry O'Neill, A Problem of Rights 
the game theory to solve a Mishnah that was completely mysterious. The game-theoretical analysis was the key to exploring the rule that introduced the particular rabbi in the particular division, a division that-before the game-theoretical investigation - no one could explain. ${ }^{5}$ The game theory had two kinds of contribution in this case: to explore what rule of division influenced a particular division and to show that the rule of division regarding two persons may be expanded to a case of more than two persons; this still provides a unique solution in any possible case of conflicting claims.

In other papers, Aumann points out that ancient Halachic scholars discussed different problems as though they had understood the important parts of economic theory ${ }^{6}$ and that complex game theory concepts appear in the Talmudic literature, and in the Talmud itself, in several different contexts. ${ }^{7}$ About a particular Talmudic passage, Aumann claims, "[i]n conclusion, there seems to be little doubt that fairly sophisticated concepts of the modern theory of risk-bearing underlie this Talmudic passage, and were well understood by its authors." 8 In several lectures, Aumann also investigated the Halachic rules of commerce and compared these with the recommendations of economic theory. Of course, it is too early to know how the field of Talmud and game theory will be developed.

There are some works that apply game theory to the Hebrew Bible; the book of Steven Brams is one such example. ${ }^{9}$ Brams's thesis is that God and the human biblical characters acted rationally; given their preferences and their knowledge of other players' preferences, they made strategic choices that led to the best attainable outcomes. ${ }^{10}$ Some game theoreticians are interested in the Biblical story of King Solomon. King Solomon asked the two women, each of whom claimed that the child was theirs, if they would agree to share the child

Arbitration from the Talmud, 2 MATHEMATICAL Soc. Scis. 345, 345 (1982). Robert J. Aumann \& Michael Maschler, Game Theoretic Analysis of a Bankruptcy Problem from the Talmud, 36 J. ECON. THEORY 195, 195 (1985).

${ }^{5}$ See Geoffrey P. Miller, Law and Economics Versus Economic Analysis of Law, 19 AM. BANKR. InST. L. REV. 459, 465 (2011) (discussing the difference between law and economics, and the economic analysis of law).

${ }^{6}$ Risk Aversion in the Talmud, supra note 1, at 235.

${ }^{7}$ Some Non-Superadditive Games, supra note 1, at 3.

${ }^{8}$ Risk Aversion in the Talmud, supra note 1, at 235.

${ }^{9}$ Steven J. Brams, Biblical games: Game theory and the Hebrew Bible (Mass. Inst. of Tech. Press ed., 2003).

${ }^{10} I d$. 
by cutting it into two. ${ }^{11}$ One woman accepted the settlement proposal, while the other rejected it, preferring that the other woman get the child. ${ }^{12}$ Thus, King Solomon gave the child to the woman who rejected the proposal. ${ }^{13}$ It is an interesting mechanism but one that can be utilized only once. If the parties in the next trial are aware of the mechanism, they will both reject the proposal and express a preference that the other woman gets the child. Therefore, the question is, what if the mechanism implemented by King Solomon could be modified to be successful, even when it is transparent? ${ }^{14}$ Game theory teaches that there may be a successful mechanism in which the mother should be asked to sacrifice something. In the case that they both agree to sacrifice something, the sacrifice should be such that the real mother, and only the real mother, will agree to make that sacrifice (for example, contributing a kidney). Then, the real mother will get the child without needing to sacrifice anything. Glazer and Ma present what they call "[e]fficient allocation of a 'prize' - King Solomon's dilemma."15

A planner is interested in allocating an indivisible good (a "prize") to one of many agents in the economy. His objective is to give the prize to the agent who values it most, without any payments being made by the recipient. The planner, however, does not know the identity of this agent, while the agents themselves do. This paper shows how the planner can construct simple, multistage mechanisms with a unique subgame perfect equilibrium outcome. At this outcome, the agent who values the prize most gets it without any transfer of money being made by any of the agents or the planner. ${ }^{16}$

${ }^{11}$ See 1 Kings 3: 16-25 (King James).

${ }^{12} I d$. at 3:26 ("Then spake the woman whose the living child was unto the king, for her bowels yearned upon her son, and she said, O my lord, give her the living child, and in no wise slay it. But the other said, Let it be neither mine nor thine, but divide it.").

${ }^{13}$ Id. at 3:27 ("Then the king answered and said, Give her the living child, and in no wise slay it: she is the mother thereof.").

${ }^{14}$ Jacob Glazer \& Ching-to Albert Ma, Efficient Allocation of a "Prize" - King Solomon's Dilemma, 1 GAMES \& ECON. BEHAV. 222, 222 (1989).

${ }^{15} I d$.

${ }^{16} I d$. 
Perry and Reny propose a generalization of Solomon's dilemma. ${ }^{17}$ There are many agents; therefore, an object must be awarded at no cost to the one agent who values it most ${ }^{18}{ }^{19}$ McCannon describes a course that introduces and uses game theory to study the Bible. ${ }^{20}$ The course is designed to build the critical thinking skills of undergraduate economics students.

The application of economic theory to the study of the Talmud preceded the application of game theory. We now present some works that apply economic theory to the study of the Talmud. Roman Ohrenstein claimed that the Talmudic rule that a judge is allowed to take a wage of no more than the value of the time the judge lost actually states that the judge's wage should not be more than the judge's opportunity cost. $^{21}$ For this, we can add a game-theoretical perspective. This law also applies to expert witnesses. ${ }^{22}$ By this, the Jewish law provides the

${ }^{17}$ Motty Perry \& Philip J. Reny, A General Solution to King Solomon's Dilemma, 26 GAMES \& ECON. BEHAV. 279, 283 (1999).

${ }^{18} \mathrm{Id}$.

${ }^{19}$ They provide a mechanism that implements this outcome in iteratively weakly undominated strategies when it is common knowledge that the agent who values the object the most knows who he or she is.

${ }^{20}$ Bryan C. McCannon, Using Game Theory and the Bible to Build Critical Thinking Skills, 38 J. ECON. EDUC. 160, 161 (2007).

${ }^{21}$ Roman A. Ohrenstein, Economic Thought in Talmudic Literature in the Light of Modern Economics, 27 AM. J. Econ. \& SociO. 185, 189 (1968).

${ }^{22}$ The reader may be interested in this long discussion in the Talmud, Ketubot Daf 105a:

The Gemara relates: The Sage Karna would take an istera, a small coin, from the innocent party, and an istera from the guilty party, i.e., he would charge both parties that came to him for judgment, and then he would judge their case. The Gemara asks: But how could he do so? Isn't it written: "And you shall take no bribe" (Exodus 23:8), which indicates that a judge may not take money from either of the two litigants?

And if you say that this prohibition against taking a bribe applies only when a judge does not take from both parties, as there is a concern that perhaps he may come to pervert the judgment in favor of the party that gave him the bribe, whereas in the case of Karna, since he took from both parties he will not come to pervert the judgment, who says that the verse is referring only to those circumstances? Is it permitted to take a bribe even in a case when one will not pervert the judgment?

But isn't it taught in a baraita: "And you shall take no bribe" (Exodus 23:8); what is the meaning when the verse states this? If it comes to teach that one should not acquit the guilty and one should not convict the innocent due to a bribe, it is already stated: "You shall not wrest judgment" (Deuteronomy 16:19). Rather, this verse teaches that even if the purpose of the bribe is to ensure that one acquit the innocent and 
witnesses an incentive not to lie, since they cannot benefit from the lie more than the time they lost. Carlton and A. Weiss pointed out that:

\section{[a]lthough Judaism has used a whole host of restrictions on competition and has had its share of legislation to promote private interests, there is one area that has gen- erally been a consistent exception in impediments to competition -- the teaching of the Torah. This exception}

convict the guilty, the Torah nevertheless says: "And you shall take no bribe." This indicates that it is prohibited for a judge to receive anything from the litigants, even if there is no concern at all that justice will be perverted.

The Gemara answers: This applies only when one takes the money in the form of a bribe, even if he does not intend to pervert the judgment, whereas Karna took the money in the form of a salary, not a bribe. The Gemara asks: But is it permitted to take money from litigants in the form of a salary? Didn't we learn in a mishna (Kiddushin 58b): With regard to one who takes a salary to judge cases, his judgments are void? The Gemara answers: This applies only when he took money as his compensation for judging the case, whereas Karna accepted the money as compensation for unemployment, i.e., as he could not engage in his usual work while dealing with the case, he would take compensation for this unemployment.

The Gemara asks: And is it permitted to take money as compensation for unemployment? Isn't it taught in a baraita: Ugly is the judge who takes a salary to judge cases; however, his judgments are valid judgments? The Gemara clarifies: What are the circumstances of this baraita? If we say that it is referring to one who accepted money as his compensation for judging, are his judgments valid judgments? But didn't we learn in a mishna (Kiddushin 58b): With regard to one who takes a salary to judge cases, his judgments are void? Rather, it must certainly be referring to a situation where he takes money as compensation for unemployment, and yet the baraita teaches: Ugly is the judge.

The Gemara answers: This statement that the judge is ugly applies only when the fact that he is taking a salary for his unemployment is not evident, as he was not engaged in some other type of work at the time. Karna, however, would take money for his unemployment when it was evident that he was taking time off work to judge the case, as he was examining people's wine stores [ambara] to see which casks would last and which were going sour, and they would pay him one dinar as a salary. Consequently, when Karna paused from his work to deal with a case, it was clear that he was losing money.

Talmud, Ketubot Daf 105a. This discussion regarding judges applied mutatis mutandis regrading witnesses. According to Rabbi David Ben Zimra, if the witness takes money for the time they lose, surely their testimony is valid. 3 Teshuvot HaRadbaz 942. We recommend considering applying this rule also to a situation in the modern law, where many experts testify before the court and get money for doing so. 
is all the more remarkable because those who were in a position to influence the legislation often stood to benefit from such restrictions. ${ }^{23}$

From this emphasis on teaching, they argued that the foundation was laid for the survival and perpetuation of Judaism. However, they ignore that women have been excluded from studying the Torah, that refutes their thesis.

The Oxford Handbook of Judaism and Economics ${ }^{24}$ explores how Judaism as a religion, and Jews as people, relate to the economic sphere of life in modern society compared to how they did so in past societies. $^{25}$

${ }^{23}$ Dennis W. Carlton \& Avi Weiss, The Economics of Religion, Jewish Survival and Jewish Attitudes Toward Competition in Torah Education, (J. of Legal Stud., Working Paper No. 7863, 2000).

24 OXford University Press, The OXford HandBook of JudAism AND ECONOMICS (Aaron Levine, ed., 2010).

${ }^{25}$ See generally id. There are also some sociological works about economics and Judaism. Karl Marx (1844), in his antisemitic period, examined and discussed:

What is the secular basis of Judaism? Practical need, self-interest. What is the worldly religion of the Jew? Huckstering. What is his worldly God? Money.

Very well then! Emancipation from huckstering and money, consequently from practical, real Judaism, would be the self-emancipation of our time.

$\cdots$

This is no isolated fact. The Jew has emancipated himself in a Jewish manner, not only because he has acquired financial power, but also because, through him and also apart from him, money has become a world power and the practical Jewish spirit has become the practical spirit of the Christian nations. The Jews have emancipated themselves insofar as the Christians have become Jews.

Karl Marx, On the Jewish Question, MARXISTS.ORG (1844), https://www.marxists.org/archive/marx/works/1844/jewish-question/.

According to Werner Sombart, "The time has come, it seems to me, for a trained economist to deal thoroughly with the economic side of the Talmud and of Rabbinic literature generally.” WERNER SOMBART, THE JEWS AND MODERN CAPITALISM 313 (1911). He claimed that the attitude of the Talmud, then, is a friendly one toward exchange, and the Jews adopted it throughout the Middle Ages. Regarding the influence of the Jewish approach toward trade, he wrote:

It is indeed surprising that the parallelism has not before been observed between Jewish wanderings and settlement on the one hand, and the economic vicissitudes of the different peoples and states on the other. Israel 


\section{B. "Game-theoretical" Reasoning in the Talmud}

The methods of "law and economics" and game theory may be used to explain some Talmudic rules since its discussion is sometimes explicitly sensitive to the consideration of incentives. Let us examine some examples of rules based on incentive reasoning:

First, the Mishnah says, "[c]aptives are not to be redeemed for more than their worth, for the general good." ${ }^{26}$ Maimonides explained that this rule was "so that enemies will not pursue people to hold them captive." 27 In other words, the goal of this rule is to limit the incentive to kidnap. The aforementioned Mishnah also makes the following determination: "captives are not to be 'smuggled out' of captivity, for the general good." 28 R. Shimon b. Gamliel used the term, "[f]or the good of the captives." 29 Thus, Maimonides explains this rule "so that enemies will not oppress captives seriously and be very strict when guarding them." 30

Second, there are a number of Halachic rules derived from the Talmudic principle "so that the sinner does not profit [from his sin]." 31 This means that the law should not be such that it would be worthwhile for an individual to sin, or in other words: a law should not be structured in a way that allows an individual to benefit from his own $\sin$.

Third, the Mishnah states:

passes over Europe like the sun: at its coming new life bursts forth; at its going all falls into decay.

Id. at 13; see Milton Friedman, Morality of the Market: Religious and ECONOMIC PERSPECTIVES 401-18 (Fraser Inst. ed.,1985) (claiming that there are few peoples, if any in the world, who owe so great a debt to free enterprise and competitive capitalism as the Jews and who have done so much to undermine the intellectual foundations of capitalism as the Jews).

${ }^{26}$ Mishnah Gittin 4:6.

${ }^{27}$ Moshe ben Maimon, Mishneh Torah: Matnot Aniyim 8:12, CHABAD, https:/www.chabad.org/library/article_cdo/aid/986709/jewish/Matnot-AniyimChapter8.htm\#lt=primary (last visited Apr. 10, 2021).

${ }^{28}$ Mishnah Gittin 4:6.

${ }^{29} \mathrm{Id}$.

${ }^{30}$ Moshe ben Maimon, Mishneh Torah: Matnot Aniyim 8:12, CHABAD, https://www.chabad.org/library/article_cdo/aid/986709/jewish/Matnot-AniyimChapter8.htm\#lt=primary (last visited Jan. 26, 2021).

${ }^{31}$ Mishnah Challah 2:7. 
In the case of two people who deposited money with one person, and this one deposited one hundred dinars and that one deposited two hundred dinars, and when they come to collect their deposit, this one says: My deposit was wo hundred dinars, and that one says: My deposit was two hundred dinars, the bailee gives one hundred dinars to this one and one hundred dinars to that one. And the rest of the money, i.e., the contested one hundred dinars, will be placed in a safe place until Elijah comes and prophetically determines the truth. Rabbi Yosei said: If so, what did the swindler lose? He lost nothing by claiming the one hundred dinars that belongs to another, and he has no incentive to admit the truth. Rather, the entire deposit will be placed in a safe place until Elijah comes. As his fraud will cause him to lose even the one hundred dinars that he deposited, perhaps he will be discouraged from making a fraudulent claim. ${ }^{32}$

Rabbi Yosei actually proposes that, in this case, the result should be that each side would get zero, which would dramatically reduce the incentive of the potential liar to lie, thereby protecting the honest person in particular.

Fourth, the Talmud says, "[t]his is a rabbinic enactment made in order that prospective borrowers should not find the door of their benefactors locked before them." 33 The Talmud designed the rules of borrowing such that it would not be disadvantageous to the borrower. The Talmud takes into account that the overprotection of borrowers may be against their interest because it would make it difficult for them to secure loans in the future. ${ }^{34}$ This led the Talmud to reform the laws regarding the rights of borrowers. ${ }^{35}$

\footnotetext{
${ }^{32}$ Mishnah Bava Metzia 3:4.

${ }^{33}$ Bava Kamma 8.

${ }^{34}$ Babylonian Talmud: Tractate Gittin Folio 49b.

35 Moreover, the Talmud also legislated against the over-protection of creditors in order to prevent their incentive to tempt the borrowers. We can see in the following Talmudic discussion an attempt to optimize between the need not to block loans, and the need not to create an incentive to tempt the borrowers to take loans against their interest:
} 
Fifth, we can find this rule in the Mishnah: "One who finds a lost object need not take an oath, for reasons of societal benefit"; ${ }^{36}$ and this is how Maimonides legislated and explained the rule:

When a person finds a lost object, he is not required to take an oath. This is a decree ordained for the benefit of society. For if a finder of a lost article were required to take an oath, he would ignore the lost article and proceed on his way so that he would not be required to take the oath. Even if a person found a wallet, and the owner of the wallet claimed that there was another wallet tied together with it, and it would be impossible to find one without finding the other tied to it, the finder is not required to take an oath. ${ }^{37}$

We can see that Maimonides is sensitive to incentives. If the finder is obliged to take an oath, they will be incentivized not to return the lost object.

Last, we now present an example of the problem of over-deterrence. Maimonides states:

When a person is hired to transfer a jug from place to place for a wage, and the jug is broken, according to Scriptural Law, he should be required to pay. For this is not a major factor that is beyond the porter's control; breaking an article is equivalent to its being stolen or lost, for which he is liable. Nevertheless, our Sages ordained that the porter should be liable merely to take an oath that he was not negligent in caring for it. For if he

\footnotetext{
Why did they lay down that a creditor should recover only from medium land? So that a man, on seeing his neighbour possessed of a fine field or a fine house, should not be tempted to say, I will induce him to borrow money of me so that I can get them on account of my debt. For this reason they laid down that a creditor should recover only from medium land. But if that is so, he should be allowed to recover only from the lowest grade? This would be closing the door in the face of borrowers.
}

Babylonian Talmud: Tractate Gittin, HALAKHAH, http://halakhah.com/gittin/gittin_49.html (last visited Apr. 10, 2021).

${ }^{36}$ Gittin 5:3.

${ }^{37}$ Moshe ben Maimon, Mishneh Torah: Gezelah va'Avedah, CHABAD, https:/www.chabad.org/library/article_cdo/aid/1088897/jewish/Gezelah-vaAvedah-Chapter-Thirteen.htm\#lt=primary (last visited Jan. 26, 2021). 
were required to make financial restitution, no person would ever carry a jug for a colleague. Therefore, the Sages ordained that the breaking of a jug is equivalent to the death or the injury of an animal. ${ }^{38}$

This means that the Jewish law regarding torts caused by workers was changed such that they would be exempted from damages ${ }^{39}$ they cause to their employees, unless they were sufficiently guilty, in order to prevent the problem of over-deterrence. ${ }^{40}$

In all of the above cases, the justification for the rules is to prevent games in which it is worthwhile to misbehave. In other words, those Talmudic rules curb incentives to misbehave. James Tobbin defined economics in one word as "incentive" and Aumann adopted this definition for game theory. ${ }^{41}$ It is clear that the Talmud sometimes discusses the effect of incentives. The game-theoretical analysis may help to understand how rules affect incentives and which rules lead to which incentives. In game theory, there is a fundamental distinction

38 Moshe ben Maimon, Mishneh Torah: Sechirut, Chabad, https://www.chabad.org/library/article_cdo/aid/1368666/jew-

ish/Sechirut-Chapter-3.htm (last visited Jan. 26, 2021).

${ }^{39}$ In the Jewish law, there is a general interesting distinction between intentional damages and unintentional damages. Although a person is responsible for the damages that they cause regardless of their intention, in the case of intentional damage, the injurer should also compensate the victim for the violation of their honor. See Tractate Bava Kama, JEWISH VIRTUAL LIBR., https://www.jewishvirtuallibrary.org/tractate-bava-kama-chapter-8 (last visited Feb. 9, 2021) ("If one falls down from a roof and causes damage and disgrace, he is liable for the damage but not for the disgrace, as the latter requires intention."). We see this distinction as important since it prevents the incentive to revenge in other ways. If there is no difference between intentional damage and unintentional damage, the injuree may feel that the compensation is not enough and thus be incentivized to avenge himself.

${ }^{40}$ See Yuval Sinai \& Benjamin Shmueli, Calabresi's and Maimonides's Tort Law Theories-A Comparative Analysis and a Preliminary Sketch of a Modern Model of Differential Pluralistic Tort Liability Based on the Two Theories, 26 YALE J. L. HUMAN. 59, 60 (2014) ("[T] he roots of contemporary utilitarian analysis can be traced back to Jewish law sources, and that the ancient model can assist us in presenting a preliminary sketch of a modern model of pluralistic tort liability."). I would say that the implicit fundamental presumption of the Talmud and the Law and Economics movements are opposite: the fundamental presumption of the Law and Economics movement is that we do not wish to achieve zero damages but an optimal number of damages. For the Talmud, at least regarding the loss of life, there is no such thing as optimal number of damages, but we should prevent loss of life.

${ }^{41}$ Robert J. Aumann, War and Peace, 103 Proc. NAT'L ACAD. SCI. U.S.A. 17075, 17076 (2006). 
between a one-time game and a repeated one. A particular behavior might be worthwhile for the agent in a one-time situation but not in a repeated one. In the language of game theory, the above rules come to prevent damage, given that the situation is repeatable. For example, paying an enormous price to liberate captives may be efficient in a onetime situation but not in repeated ones. This is also the case with the overprotection of borrowers.

We can also find some economical recommendation for the individual in the Talmud, recommendations that may be analyzed via the tools of game theory and economic theory. R. Isaac said, "one's money should always be ready to hand, for it is written, and thou shalt bind up the money in thy hand." ${ }^{42} \mathrm{R}$. Isaac also said that one should always divide his wealth into three parts: investing a third in land, a third in merchandise, and keeping a third ready to hand. ${ }^{43}$

The first recommendation is actually a recommendation about fluidity, such that the person will not lose economic opportunities. The second recommendation is about risk distribution. It is interesting that this advice was given centuries before the raising of the theory of insurance and risks. The Talmud even discusses how to become a rich person:

The sages of Alexandria asked: What should a person do to become wealthy? Rabbi Yehoshua said to them: $\mathrm{He}$ should increase his time involved in merchandise and conduct his business faithfully. The sages of Alexandria said to Rabbi Yehoshua: Many people have done so, and it did not help them become rich. Rabbi Yehoshua replied: Rather, they should pray for mercy to receive wisdom from the One to Whom wealth belongs,

${ }^{42}$ Babylonian Talmud: Tractate Baba Mezi'a 42a, HALAKHAH, https://halakhah.com/babamezia/babamezia_42.html\#42a_4 (last visited Apr. 10, 2021).

${ }^{43}$ Talmud, Bava Metzia 42A:

Rava says that Rabbi Yitzhak said: The verse states: "And you shall bind up the money in your hand" (Deuteronomy 14:25), from which it is derived: Although it is bound, in order to safeguard the money, it must be in your hand.

And apropos that verse, Rabbi Yitzhak says: A person's money should always be found in his possession. He should not invest all of his money, leaving him with no money available for expenditures, as it is stated: "And you shall bind up the money in your hand.

SEFARIA, https://www.sefaria.org/Bava_Metzia.42a?lang=en (last visited Jan. 26, 2021). 
as it is stated: "Mine is the silver, and Mine the gold, says the Lord of hosts" (Haggai 2:8). ${ }^{44}$

Game theory can help us to understand why R. Hiyya is right. Since business is voluntary, the two sides gain from playing this game, and in order to make it possible to play this game, people should have a reputation of being honest in their business. The most important aspect of the Talmud regarding business is the statement: "[h]e who wants to be wise let him occupy himself with cases dealing with monetary matters, for there is no greater branch of Torah than this; for they are like a welling fountain." 45 This statement actually encourages a rational discussion regarding monetary issues. It is not just that it is legitimate to talk about money but that such discussion is encouraged. Rational discussion regarding monetary issues leads to better legal rules regarding trade, better economic decisions, and more transparency.

\section{TALMUdiC GAMES OF RESPONSIBILITY}

\section{A. The Talmudic Comedy of the Commons}

Let us look at this rule in the Mishna: "If a pit belonging to two partners was uncovered and the first partner passed by it and did not cover it, and then the second passed by it and did not cover it, the second is liable for any damage caused by means of the pit." 46 The rule in Maimonides is the opposite, as it imposes full responsibility on the first partner:

The following rules apply when] a cistern is owned by two partners. If the first passed by and did not cover it, and then the second passed by and did not cover it, the first is liable until he gives his buckets to the second [partner]. Once he gives his buckets to the second

\footnotetext{
${ }^{44}$ Talmud, Niddah 70b, SEFARIA, https://www.sefaria.org/Niddah.70b?lang=bi (last visited Apr. 10, 2021).

${ }^{45}$ Mishna Bava Barta 10:8, SEFARIA, https://www.sefaria.org/Mishnah_Bava_Batra.10.8? lang=bi. This Mishna is discussed by the Talmud, Bava Batra $175 \mathrm{~b}$ https://www.sefaria.org/Bava_Batra.175b?lang=bi.

${ }^{46}$ Mishna Bava Kamma 5:6.
} 
partner to draw water from it, the first is freed of liability, and the second becomes liable. ${ }^{47}$

What is consistent in this halachic discussion, is that the liability is imposed on one partner and only on that partner. On the surface, it is a strange rule. Why should it be so? Should not the fair solution divide the liability for the damage between the two of them? The right reasoning will teach that they are equally responsible. Here is the place where game theory changes the picture. This is exactly the problem of the tragedy of the commons in Hardin. ${ }^{48}$ If the responsibility is divided, there may be a prisoner's dilemma. ${ }^{49}$ Let us assume that the

47 Moshe ben Maimon, Mishneh Torah: Hilchot Nizkei Mamon, CHABAD, https://www.chabad.org/library/article_cdo/aid/682977/jewish/Hilchot-NizkeiMamon-Chapter-Twelve.htm\#lt=primary (last visited Jan. 26, 2021). One of the commentators on Maimonides, Rabbi Abraham de Boton (1560-1605) claimed in his book, Lehem Mishne, that Maimonides had a manuscript of the Mishnah; accordingly, the first one is liable. See Lehem Mishne 1:1. The Talmud in Bava Kamma $51 \mathrm{~b}$ reinterpreted the Mishnah that imposes liability (only) on the second one that it is a case in which the first one transfers a pail to the second in order to use the pit, or in order to cover the pit. (There is a dispute between the Talmudic scholars, what exempts the first from responsibility: the transferring of the use or the transferring of the responsibility to cover). The Talmud discussed a manuscript of the Mishnah in which the first is liable. We may learn from the proposal that Maimonides had a different manuscript of the Mishna, that it was difficult for the commentator to handle the fact that Maimonides decided against the Mishna. See Talmud Bava Kamma 51b, Sefaria, https://www.sefaria.org/Bava_Kamma.51b?lang=en (last visited Jan. 26, 2021).

${ }^{48}$ Garrett Hardin, The Tragedy of the Commons, 162 SCI. 1243,1244-45 (1968).

${ }^{49}$ Prisoner's dilemma: suppose the police arrests two individuals for possession illegal weapons near a bank immediately after an armed robbery took place there. The police have strong enough evidence to charge them with the minor infringement that incurs a lenient penalty, but not enough evidence to charge them with the severe infringement that incurs a severe penalty. To achieve that the police isolate them and propose each of them a plea-bargain. The options that the game offers are then as follows. If they both betray each other, they will both receive medium penalty; if they cooperate with each other and keep silent, then they will both receive the lenient penalty. If only one betrays the other, then that one will walk, and the other will receive the severe penalty. The outcomes then are A(freedom), B (lenient penalty), $\mathrm{C}$ (medium penalty) and D (severe penalty): 
expected damage is twelve, and the cost of covering the pit is ten. In that case, no partner will cover the pit (when transaction cost prevents agreements). ${ }^{50}$ The situation (under the equal liability rule) defines a classical prisoner's dilemma as shown below. ${ }^{51}$

Table 1. The Covering Dilemma Matrix

\begin{tabular}{|l|l|l|}
\hline & Cover the pit & Do not cover the pit \\
\hline Cover the pit & $-5,-5$ & $-10,0$ \\
\hline Do not cover the pit & $0,-10$ & $-6,-6$ \\
\hline
\end{tabular}

In contrast, according to the rule of Maimonides, the first partner is sufficiently incentivized to cover the pit. According to the rule of the Mishna, the first partner will rely on the second if the first partner knows that the second is expected to see the pit. This rule adequately incentivizes the second one but is open for accidents. Let us assume that the first one knows that there is a $50 \%$ probability that the second will see the pit. In this case, the rational first partner will not cover the pit, and there is a $50 \%$ probability that the second one will also not cover the pit. ${ }^{52}$ We can see three potential rules for this

Table 2. Prisoner's Dilemma

\begin{tabular}{|l|l|l|}
\hline & Cooperate & Defect \\
\hline Cooperate & B, B & D, A \\
\hline Defect & A, D & C, C \\
\hline
\end{tabular}

${ }^{50}$ When there is no transaction cost, the pit will be covered regardless of the legal rule. Thus, when we seek to minimize negligence (especially in the case of partnership), we should be interested particularly in situations in which there are significant transaction costs.

${ }^{51}$ We assume that mutual cooperation, in which each side pays 5, is a possible option of this game. This may be, for example, the case when the player who did not cover has the choice to pay the other partner who covered half of their costs. When it is impossible, there may be another game: the first player will have the choice to cover the pit, and if the first player does not cover the pit, the second player will have this choice. (We can call this game "the pit game"). It will be in the best interest of each player not to cover the pit under the rule of equal distribution of the liability, and thus the pit will not be covered. However, the rule proposed by Maimonides or the Mishna prevents this undesirable game.

${ }^{52}$ On the other hand, one may challenge and say, "Hey, maybe the game will be that the person who sees the pit does not know if they are the first or the second." We say Maimonides' rule gives the seer a signal that he is not the second, since 
particular game. We argue that the best is the one proposed by Maimonides, the second-best is the rule proposed by the Mishna, and the worst is the equal distribution of the liability ${ }^{53}$ (which, to the best of the author's knowledge, is the rule in the modern legal systems).

Actually, Jewish law enables partnership and is aware of its disadvantages. ${ }^{54}$ Rav Kahana says, "[a] pot belonging to partners is neither hot nor cold." 55 However, in torts, it imposes responsibility (only) on one of the partners in different cases, thus preventing the commons' tragedy. ${ }^{56}$ In this way, the Talmud prevents the partnership from externalizing the partnership's social price. The victim always prefers the blocking of the damage to compensation because of the litigation cost. The Rashbam, a prominent commentator on the Talmud, said that even if the injurer accepts responsibility for any damage, people do not wish to be injured and then litigate because of the litigation

otherwise the first would have probably covered the pit; at least there is no sufficient evidence that someone else was first. This is another advantage with the rule proposed by Maimonides.

${ }^{53}$ There are some important Rabbis, such as Rabbi Jacob ben Asher (1269-1343), and Rabbi David HaLevi Segal (1586-1667) who proposed such a rule.

54 See Talmud, Bava Batra 13a, SEFARIA, https://www.sefaria.org/Bava_Batra.13a.2?lang=bi\&with=all\&lang2=en (last visited Jan. 26, 2021) (explaining that the Jewish law enables partnership, but it regulates it such that if the garden is big enough (such that each partner gets 2 meters on 2 meters), then each partner has the right to demand the division of the garden between the partners. This way, the game is different (in big enough gardens) from the tragedy of the commons, since every partner knows that the other partner has the right to stop playing and force a change in the game. The difference between such a partnership and a partnership without the right to force division is like the difference between a marriage without the right to divorce and a marriage with the right to divorce. Even if the garden is not big enough, a partner has a legal right to demand that this is my proposed price. Sell me your part for this price or I will buy your part for this price.) This is similar to the game in which one divides the cake, and the second chooses.

55 Talmud, Bava Batra 24b, SeFARIA, https://www.sefaria.org/Bava_Batra.24b?lang=bi (last visited Jan. 26, 2021).

${ }^{56}$ One of the commentators of Maimonides, Melech Shalem, explained his view by arguing that Maimonides adopted the Talmudic view that, in the case of partnership, we can say which part belongs to which partner even in the period that they are partners. This explanation implies that Maimonides has a weak view of partnership, such that even in the period of the partnership, there is a kind of division. I would interpret that he understands Maimonides, such that when the partner was the first to pass the pit, he became the partner who is responsible for the pit until he passes the responsibility. 
cost. $^{57}$ This is a crucial difference between the Rashbam and the Learned Hand Rule, and maybe even between the Rashbam and the students of Coase. ${ }^{58}$ The point of the Rashbam may be translated into the following words: When we calculate the damage, we should take into account the litigation cost needed to fulfill the right.

\section{B. The Talmudic Prisoner's Dilemma}

\section{i. $\quad$ Talmudic Background}

This is the Talmudic passage that designs the rules regarding testimonies about joint crime: ${ }^{59}$

R. Joseph again said: 'If a man says that so and so committed sodomy with him against his will, he himself with another witness can combine to testify to the crime. If, however, he admits that he acceded to the act, he is a wicked man [and therefore disqualified from acting as witness] since the Torah says: 'Put not thy hand with the wicked to be an unrighteous witness.' Raba said: 'Every man is considered a relative to himself, and no one can incriminate himself. ${ }^{60}$

To obtain a person's criminal conviction in Talmudic law, it is a sine qua non to have at least two kosher witnesses. Now, what should the law be if, for example, two people voluntarily commit a homosexual act (mishkav zachar) in the eyes of a third kosher Jew as a witness? The judges need two kosher witnesses to convict them of this "crime." If a person testifies against their partner and a third person, can the court convict that person? Can the testimony of the homosexual partner be valid, given that the partner had homosexual relations?

57 Talmud, Bava Batra 60a, SEFARIA, https://www.sefaria.org/Bava_Batra.60a?lang=bi (last visited Jan. 18, 2021).

${ }^{58}$ Ronald H. Coase, The Problem of Social Cost, 3 J. OF L. \& ECON. 1, 2 (1960).

${ }^{59}$ Deuteronomy 19:8 (King James) ("And if the LORD thy God enlarge thy coast, as he hath sworn unto thy fathers, and give thee all the land which he promised to give unto thy fathers ...").

60 Babylonian Talmud: Tractate Sanhedrin, HALAKHAH, http://www.halakhah.com/sanhedrin/sanhedrin_9.html (last visited Jan. 26, 2021). 
There is a controversy between Rabbi Joseph and Raba in the Talmud. ${ }^{61}$ Rabbi Joseph determined that the testimony is rejected since the rule is that a wicked person cannot be a witness ("Put not thy hand with the wicked to be an unrighteous witness"). ${ }^{62}$ Contrary to that position, Rabbah determines that if one of the homosexual partners testifies that "the other person had homosexual intercourse with me in accordance with my will," the court would adopt only the first part of the person's testimony, viz. the part that the other person had homosexual intercourse with the person (which will neutralize the other person's capacity to testify) but not the last part of their testimony, i.e., that it was voluntary intercourse. ${ }^{63}$ This result is consistent with the Talmudic reasoning that the court does not recognize a person's power to testify against oneself in criminal law ${ }^{64}$. Although the witness committed the crime of homosexuality in real life and is therefore not a kosher witness, the court does not recognize that the person is homosexual, since a testimony against oneself is unacceptable. Agassi argues that, in the Talmudic discourse, even factual questions are legal questions that can be decided contrary to how the judge sees the actual reality. ${ }^{65} \mathrm{We}$ can see the Talmudic rule discussed above as an individual instance of this methodological principle.

It should be noted that, as in other discussions in the Talmud, the discussion about punishing homosexuals is only a theoretical one from the Talmudic point of view. Since the Talmud constitutively denies the existence of homosexual Jews, "Israel is suspected of neither pederasty nor bestiality" 66 and is not interested in homosexual Gentiles. Therefore, although mishkav zachar is usually translated as "sodomy," it should not be considered with reference to a real-life homosexual relationship; instead, it should be considered as a hypothetical

${ }^{61} I d$.

${ }^{62} \mathrm{Id}$.

${ }^{63}$ Can we conclude from this that this interpretation does not distinguish homosexual rape from a voluntary homosexual relationship? The Tosafot interpreted that the court deletes even the words "with me," perhaps because they wish to distinguish homosexual rape from a consensual homosexual relationship.

64 Babylonian Talmud: Tractate Sanhedrin, HALAKHAH, http://www.halakhah.com/sanhedrin/sanhedrin_9.html (last visited Jan. 26, 2021).

${ }^{65}$ Joseph Agassi, Conventions of Knowledge in Talmudic Law, 25 J. OF JEWISH STUD. 1, 26 (1974).

${ }^{66}$ Kiddushin 82a. 
sexual relationship. ${ }^{67}$ Regardless, this paper does not discuss the Talmud values concerning human rights (the homophobic parts of the Talmud should not be hidden) but examines the games that are created and avoided by several Talmudic rules. We are interested in the sophistication of the Talmudic mechanisms.

\section{ii. $\quad$ Game-theoretical Analysis}

We argue that Rabbah's conclusion is consistent with the internal reasoning of Talmudic law. Let us now argue that Rabbah's rule is also efficient because it intends to optimize "criminal" deterrence. When we translate the rule of Rabbah into a game-theoretical matrix, we should decide what precisely the interpretation of this rule is. One of the advantages of game theory is that it may make the discussion more transparent. ${ }^{68}$ Halachic literature has not systematically discussed the rule of Rabbah. This is not a surprise. Jewish criminal law-especially those laws that involve capital punishment - is generally a theoretical corpus. Maimonides said, "40 years before the destruction of the Temple, capital punishment was nullified among the Jewish people." ${ }^{69}$

We will discuss three different possible interpretations of Rabbah's rule. In this sub-chapter, we interpret the law proposed by Rabbah to mean that a criminal who is the first to testify against his partner wins a full pardon, and the court cannot convict him in the future, even if further evidence is found. In the next sub-chapter, we will interpret this to mean that a criminal who is the first to testify against his partner neutralizes the partner's capacity to testify against him. Still, that person does not get a full pardon. This means that if two other kosher witnesses testify against the person after the person's testimony against the person's partner, the person will be convicted. Finally, we will

${ }^{67}$ See Uri Weiss, The Talmud Neutralized the Prohibition of Male Intercourse, HEVRUTA (June 5, 2013), https://havruta.org.il/2013/06/05/\%D7\%94\%D7\%AA\%D7\%9C\%D7\%9E\%D7\%95 $\% \mathrm{D} 7 \% 93-\% \mathrm{D} 7 \% \mathrm{~A} 0 \% \mathrm{D} 7 \% 98 \% \mathrm{D} 7 \% \mathrm{~A} 8 \% \mathrm{D} 7 \% 9 \mathrm{C}-\% \mathrm{D} 7 \% 90 \% \mathrm{D} 7 \% \mathrm{AA}-$ $\% \mathrm{D} 7 \% 90 \% \mathrm{D} 7 \% 99 \% \mathrm{D} 7 \% \mathrm{~A} 1 \% \mathrm{D} 7 \% 95 \% \mathrm{D} 7 \% \mathrm{~A} 8-$ $\% \mathrm{D} 7 \% 9 \mathrm{E} \% \mathrm{D} 7 \% \mathrm{~A} 9 \% \mathrm{D} 7 \% 9 \mathrm{~B} \% \mathrm{D} 7 \% 91-\% \mathrm{D} 7 \% 96 \% \mathrm{D} 7 \% 9 \mathrm{~B} \% \mathrm{D} 7 \% \mathrm{~A} 8 /$. ${ }^{68}$ See Uri Weiss \& Joseph Agassi, The Game Theory of The European Union Versus the Pax Romana, DEPAUL L. REV. (forthcoming).

${ }^{69}$ Moshe ben Maimon, Sanhedrin veha'Onashin haMesurin lahem, CHABAD, https://www.chabad.org/library/article_cdo/aid/1172737/jewish/Sanhedrin-vehaOnashin-haMesurin-lahem-Chapter-14.htm. 
analyze another interpretation of this rule: this rule is not symmetrical in the sense that it gives only the passive homosexual partner the capacity to testify against the active one. Understanding each possible interpretation can enrich the discussion of criminal law and economics because these mechanisms present us with more alternatives.

Before analyzing the Talmudic rule, let us examine one possible alternative rule. If the rule is that the testimony of a person who committed a joint crime may be used against that person, then keeping silent is the likely result of this game. No criminal will testify against his criminal partner because it is against his self-interest. More precisely, if a person who testifies does not receive a more lenient punishment in the case of a joint crime, it is sufficient that each partner believes that there is a finite probability that the partner will not testify for this game to end in mutual maintenance of silence. If each partner believes that there is a zero percent probability that the partner will not testify, then mutual testifying is a possible result of the game.

However, what would the result be if the rule were that a criminal who is the first to testify against his partner wins a full pardon? If the probability that the criminal will be caught in a case of cooperation between the criminals (i.e., mutually maintaining silence) were high enough, then the result is a Prisoner's Dilemma game ${ }^{70}$ in which it is in the best interest of each criminal to rush to testify regardless of the choice of the other. Hence, each criminal would run to testify against his partner. In contrast to a regular Prisoner's Dilemma, the criminals would testify even before the police suggest plea-bargaining and before a police investigation begins. However, if the probability that the criminal will be caught in the case of cooperation between the criminals (i.e., mutually maintaining silence) is low enough, then we would have a Stag Hunt Game. ${ }^{71}$ The result would be dependent on the norm

\footnotetext{
${ }^{70}$ Unless the friendship is so strong — or the punishment is so lenient — that they prefer friendship to punishment even when there is a $100 \%$ probability of punishment.

${ }^{71}$ In the Stag Hunt Game, two hunters choose simultaneously whether to hunt a stag or rabbits. When a successful Stag Hunt requires two hunters whereas going for rabbits, one hunter is assured of success. It is then best for both if both go for the stag; but otherwise, it is wiser to go for rabbits. Going for rabbits, one hunter prefers the other to go for the stag. Consider then four levels of success, from A to D:
}

Table 3. Stag Hunt 
in the criminal community of those two specific individuals. While the criminals might testify against each other, the outcome would depend on the degree of trust between them. In the Stag Hunt situation, if each criminal believes that the other will testify against them, then the result will be that each one will testify against the other. Insofar as that belief holds well, the prediction fulfills itself. Let us illustrate this with a concrete example: Anne will testify against Bob if she believes that Bob will testify against her. Bob will testify against Anne if he believes that Anne will testify against him. Bob believes that Anne will testify against him if Bob believes that Anne believes that Bob will testify against her. Anne believes that Bob will testify against her if she believes that Bob thinks that she will testify against him. ${ }^{72}$

This is a self-fulfilling prophecy.

\begin{tabular}{|l|l|l|}
\hline & Cooperate & Defect \\
\hline Cooperate & A, A & D, B \\
\hline Defect & B, D & C, C \\
\hline
\end{tabular}

${ }^{72}$ Let us model the situation and see when we arrive at a Prisoner's Dilemma game and when we arrive at a Stag Hunt Game, as follows:

$\mathrm{S}$ - the sanction on the convicted criminal.

$\mathrm{P}$ - the probability that the criminal will be caught when no criminal testifies against his partner.

$\mathrm{F}$ - the benefit to each criminal, which comes from keeping the friendship itself; what happens in the case that neither of them testifies against the other.

If both criminals decide and rush to testify, then there is a lottery concerning who is the first to testify. This lottery neutralizes the capacity of the other to testify against the first one.

The payoff matrix would be as follows:

Table 4. The Talmudic Prisoner's Dilemma

\begin{tabular}{|l|l|l|}
\hline & Testify & Not testify \\
\hline Testify & $-\mathrm{S} / 2,-\mathrm{S} / 2$ & $0,-\mathrm{S}$ \\
\hline Not testify & $-\mathrm{S}, 0$ & F - SP, F - SP \\
\hline
\end{tabular}

Therefore, if $\mathrm{F}-\mathrm{SP}<0$, then the game that the criminals play is of the Prisoner's Dilemma type. However, if $\mathrm{F}-\mathrm{SP}>0$, then the game the criminals play is a Stag Hunt one.

This means that when $\mathrm{F}-\mathrm{SP}<0$, i.e., when $\mathrm{P}>\mathrm{F} / \mathrm{S}$, the matrix would be as follows:

Table 5. Prisoner's Dilemma Matrix 


\begin{tabular}{|l|l|l|}
\hline Testify & sub-medium, sub-medium & best, worst \\
\hline Not testify & worst, best & medium, medium \\
\hline
\end{tabular}

This is a matrix of the Prisoner's Dilemma, and the result will be that both prisoners testify.

However, if $\mathrm{F}-\mathrm{SP}>0$, i.e., when $\mathrm{P}<\mathrm{F} / \mathrm{S}$, the matrix will be as follows:

Table 6. A Stag Hunt Game Matrix

\begin{tabular}{|l|l|l|}
\hline & Testify & Not testify \\
\hline Testify & sub-medium, sub-medium & medium, worst \\
\hline Not testify & worst, medium & best, best \\
\hline
\end{tabular}

This is a Stag Hunt matrix. This time, mutual testifying will be in the form of a Nash equilibrium for the game, as will be mutual non-testifying (a game is in a Nash equilibrium if no player can benefit from unilaterally changing their strategy). If the criminals play in a society in which the norm is mutual testifying, then the result will be mutual testifying. However, if the criminals play in a society in which the norm is mutual maintaining of silence (i.e., mutual non-testifying), then the result will be that neither of them will testify.

Let us now see what happens when the criminal testifying first receives a partial pardon. This time the criminal will bear $\mathrm{q}$ of the sanction, such that $1<\mathrm{q}<0$. Therefore, the matrix will be as follows:

Table 7.

\begin{tabular}{|l|l|l|}
\hline & Testify & Not testify \\
\hline Testify & $-\mathrm{S}(1+\mathrm{q}) / 2,-\mathrm{S}(1+\mathrm{q}) / 2$ & $-\mathrm{qS},-\mathrm{S}$ \\
\hline Not testify & $-\mathrm{S},-\mathrm{qS}$ & $\mathrm{F}-\mathrm{SP}, \mathrm{F}-\mathrm{SP}$ \\
\hline
\end{tabular}

In this instance, if one player testifies and the other does not, the player who testifies will bear a punishment of qS, and the other player will bear a punishment of S. However, if they both choose to testify, then each of them has a fifty percent probability of being punished by $\mathrm{S}$ and a fifty percent probability of being punished by qS.

This time, if $\mathrm{F}-\mathrm{SP}<-\mathrm{qS}$, i.e., if $\mathrm{P}>(\mathrm{F}+\mathrm{qS}) / \mathrm{S}$, then, the situation is that of a Prisoner's Dilemma game. However, if $\mathrm{F}-\mathrm{SP}>-\mathrm{qS}$, i.e., if $\mathrm{P}<(\mathrm{F}+\mathrm{qS}) / \mathrm{S}$, then the situation is that of a Stag Hunt Game.

Testifying is a risk-dominant strategy in this symmetric game, if and only if $\mathrm{S}(1+\mathrm{q}) / 2-\mathrm{qS}>-\mathrm{S}+\mathrm{F}-\mathrm{SP}$, i.e. if and only if $-\mathrm{S} / 2-\mathrm{q} / 2-\mathrm{qS}>-\mathrm{S}+\mathrm{F}-\mathrm{SP}$, i.e. if and only if $\mathrm{q}(1 / 2+\mathrm{S})>-\mathrm{S} / 2+\mathrm{F}-\mathrm{SP}$, i.e., if and only if $\mathrm{q}<(\mathrm{F}-\mathrm{S} / 2-\mathrm{SP}) /(\mathrm{S}+1 / 2)$.

What can we learn from the matrix? The greater $\mathrm{q}$ is, the more situations will be of the Prisoner's Dilemma type, instead of the Stag Hunt type. $1<\mathrm{q}<0$, and therefore, the maximal number of Prisoner's Dilemma situations, would be when $\mathrm{q}=0$, i.e., when the criminal receives a full pardon (not only a partial one). Therefore, the maximum number of testimonies would be in the case where a full pardon is granted. This is exactly the rule proposed by Rabbah in the Talmud. Furthermore, even if the 
The Jewish law encourages a criminal to testify against his partner, thereby increasing deterrence. However, the "price" of the above rule is that the criminal may obtain a pardon even in cases where otherwise both criminals would be convicted due to other witnesses' testimonies.

\section{iii. The Dilemma from a Waldian Perspective}

We now propose an analysis from the point of view of Abraham Wald's theory. ${ }^{73}$ Wald's theory recommends choosing between two potential mistakes. The paradigmatic example of this theory is that a person should determine whether or not to take an umbrella. ${ }^{74}$ Thus, he or she should choose between two potential mistakes: not taking an umbrella and missing it in the case of rain or taking an umbrella and carrying it without benefit in the case of no rain. As we can see, Wald's theory does not include probabilities.

Let us apply Wald's theory. We argue: the Talmudic rule creates a game in which each player, in the case of "joint crime," should choose between two potential mistakes. If the player does not testify, the player may be punished in the case that his friend betrays them. If the player testifies, the players may betray his friend without any justification if his friend does not testify against them. This is a tragic dilemma that people do not wish to face and, therefore, avoid the prohibited joint act. The Talmudic rule leads people to enter into such a dilemma when they commit the forbidden deed. This is a sophisticated mechanism of deterrence. Contrary to the prisoner's dilemma in which it is a dominant strategy to defect, the Talmudic prisoner's dilemma is a real dilemma.

\footnotetext{
situation in question were that of a Stag Hunt Game, the smaller q is, the greater the pardon, and then the probability of arriving at a norm of mutual testifying is greater. This is the case in which the players play a risk-dominant strategy.

${ }^{73}$ Abraham Wald, Statistical Decision Functions Which Minimize the Maximum Risk, 46 ANNALS OF MATHEMATiCs 265, 265 (1945); ABRAHAM WALD, STATiSTiCAL DeCision FunCtions 1 (John Wiley \& Sons, Inc. eds., 5th ed.1950).

${ }^{74}$ See generally Leonard J. Savage, The Theory of Statistical Decision, 46 J. AM. StAT. ASS'N 55 (1951).
} 


\section{The Narrow Talmudic Prisoner's DilemMa}

In the above discussion, we interpreted the rule proposed by Rabbah to mean that the first to testify against his partner wins a full pardon. Another interpretation may be that the first to testify does not win a full pardon and only receives two benefits. One is that his testimony cannot be used against him (and it will not bring about an investigation against him, and second, he is first to neutralize the ability of his partner to testify against him. ${ }^{75}$ In this situation, the testimony will not influence the outcome if there is enough evidence to convict the criminal or if there is not enough evidence to convict the partner, regardless of his testimony. The matrix of the game when the actions of the players might influence the outcome, i.e., when there is only one additional witness, will be as follows:

Table 8. The Narrow Talmudic Dilemma (Stag Hunt Game) Matrix

\begin{tabular}{|l|l|l|}
\hline & Testify & Not testify \\
\hline Testify & $\begin{array}{l}\text { Half Punishment, Half } \\
\text { Punishment }\end{array}$ & 0, Punishment \\
\hline Not testify & Punishment, 0 & Friendship, Friendship \\
\hline
\end{tabular}

This is a Stag Hunt Game. Again, if the criminals play in a society where mutual testifying is the norm, then the result will be mutual testifying. However, suppose the criminals play in a society in which mutual maintaining of silence (i.e., mutual non-testifying) is the norm. In that case, the result will be that neither of them will testify. Therefore, if the standard among "criminals" is to testify against their partners, the rule proposed by Rabbah, and its narrow interpretation, will effectively deter potential criminals from committing "crimes." If the norm among "criminals" is to not testify against their partners, the rule proposed by Rabbah in its narrow interpretation will not effectively deter potential criminals from committing "crimes."

Since Rabbah proposes a full reduction and a discount, this increases the likelihood of achieving a norm of mutual testifying. It logically follows that the desirability of a particular legal rule depends on

${ }^{75}$ Maybe this is the right interpretation since this is the meaning of ignoring the testimony of a person against himself. 
society's social norm; specifically, the legal rule of testimony in criminal law depends on the social norms among potential criminals.

\section{LITERATURE REVIEW}

Let us compare the previously mentioned Talmudic law of testimonies with the Prisoner's Dilemma. In the Prisoner's Dilemma, the police suggest that the criminal testifies against his or her partner to consider release or a reduction in punishment. ${ }^{76}$ However, the police first need to catch this criminal. No criminal has an incentive to go to the police to testify against his or her partner in consideration of a reduction in punishment. The criminal knows that, in this case, the police can initiate an investigation and propose the same plea-bargaining agreement to his or her partner, i.e., to convince the partner to testify against him or her. Talmudic law, in contrast, provides that the criminal who is the first to testify gets an almost full pardon. This is an efficient rule for the purpose of deterring criminal activity. It seems that the police give an advantage to the "prisoner" who comes to pleabargaining first and is ready to testify against the partner in real life.

The Talmudic mechanism is similar to Yadlin's proposal, which is to entrust criminals "with the right to file a private suit and to collect a fine from their accomplices." to a person who testifies against his criminal partner, which incentivizes him or her to testify before the police initiate an investigation. ${ }^{78}$ Cooter and Garoupa propose, "[t]he state should offer amnesty and a bounty to the criminal who first secures punishment of the other participant in a cooperative crime." ${ }^{.79}$ This is similar to the Talmudic mechanism but with a vast difference: the Talmud offers amnesty but not a bounty.

The main difference between the Yadlin-Cooter-Garoupa proposal and the Talmudic mechanism is that the latter does not create the problem of incentivizing a person to commit a joint crime to gain from denouncing the partner, such as in the Yadlin-Cooter-Garoupa

${ }^{76}$ See generally Weiss \& Agassi, supra note 66.

${ }^{77}$ Omri Yadlin, The Conspirator Dilemma: Introducing the "Trojan Horse" Enforcement Strategy, 2 REV. OF L. \& ECON. 25 (2006).

${ }^{78} \mathrm{Id}$.

${ }^{79}$ Robert Cooter \& Nuno Garoupa, The Virtuous Circle of Distrust: A Mechanism to Deter Bribes and Other Cooperative Crimes, UC BERKLEY (Nov. 7, 2000), https://escholarship.org/uc/item/83c0k3wc. 
proposal. Another difference is that, as described by Cooter and Garoupa, there is a big problem in their request (which is also applicable to Yadlin's), "[a] practical difficulty with such a bounty system is that people may falsely accuse others to claim a reward." do not exist in the Talmudic mechanism since the upper boundary of the gain from testifying is exempted from punishment for the testified crime. This also makes the testimony more credible than it would be in a system in which individuals gain money from their testimony. Furthermore, since the Talmudic rule does not give the testifying partner more than exemption from punishment for the testified crime, it appears that the rule does not provide the testifying partner a credible threat to implicate an innocent person.

\section{A. The Case of Bribery}

In his Nobel Lecture, Aumann said this about the crime of bribery:

Much of society is held together by this kind of reasoning. If a policeman stops you for speeding, you do not offer him a bribe, because you are afraid that he will turn you in for offering a fix. But why should he not accept the bribe? Because he is fearful that you will turn him in for accepting it. But why would you turn him in? Because if you don't, he might turn you in for not turning him in. And so on. ${ }^{81}$

Is Aumann's analysis correct? The conclusion from the above discussion is that Aumann's statement sometimes holds true and sometimes it does not, depending on the game we play. ${ }^{82}$ Suppose the rule is that the one who testifies against one's partner does not receive any leniency in punishment. In that case, the conclusion is that Aumann's statement does not hold true because, in this case, the police officer who took a bribe has no incentive to testify against the citizen. The

${ }^{80} \mathrm{Id}$.

${ }^{81}$ War and Peace, supra note 40, at 17077.

82 Aumann's statement failed to make the following distinction, and thus his statement is therefore false. Aumann proposed insight that is relevant only to some games, but not to others. Aumann did not describe the game and did not ask what the game is, or what game should be played. 
citizen who offered a bribe has no incentive to testify against the police officer. However, if the rule is such as that in the Talmud, then Aumann is right, unless the value of friendship between the criminals is greater than their expected punishment, in which case neither the citizen nor the police officer testifies ${ }^{83}$. Moreover, the norm in the Stag Hunt Game is that of mutual trust; thus, in order for society to be held together as described by Aumann, the law needs to incentivize criminal partners to testify.

Let us now propose two modifications to Aumann's example. First, if the person who proposes the bribe may be a police agent in the eyes of the offeree, that fact alone might be sufficient to deter him or her from accepting the bribe ${ }^{84}$. We, therefore, see the possibility that a police agent provocateur might deter effectively. However, this mechanism is not a legitimate one in the eyes of the Talmud because the Torah teaches, "[d]o not put a stumbling-block before the blind." 85 The Talmud discusses this in Kidushin 32b:

R. Huna tore up silk in his son Rabbah's presence, saying: 'I will go and see whether he flies into a temper or not. But perhaps he would get angry, and then he [R. Huna] would violate, Thou shalt not put a stumblingblock before the blind? - He renounced his honour for him. But he [R. Huna] violated, Thou shalt not destroy [the trees thereof...]?- He did it in the seam. Then perhaps that was why he displayed no temper? - He did it when he was [already] in a temper. ${ }^{86}$

Second, the specific Torah law of bribery deems it a crime to take a bribe but not a crime to give bribes. ${ }^{87}$ This law incentivizes bribe-givers. What incentivizes a person not to take a bribe? The bribe-taker may be subject to extortion by the bribe-giver. Rabbi Haim Shaulzon pointed out that the Jewish law of bribery makes the bribe-

\footnotetext{
${ }^{83}$ i.e., $\mathrm{F}-\mathrm{SP}>0$.

${ }^{84}$ More precisely, if there is a probability " $x$ " that the citizen who offers the fix is a police agent, and the sanction for bribe-taking is "s," and the value of money is " $\mathrm{m}$," then the corrupted police officer will not take the bribe if, and only if, " $x>m / s$."

${ }^{85}$ Leviticus 19:14.

${ }^{86}$ Talmud, Kidushin 32b.

${ }^{87}$ Deuteronomy 27:25 (King James) ("Cursed be he that taketh reward to slay an innocent person. And all the people shall say, Amen.”).
} 
taker a slave of the bribe-giver, which prevents bribery. ${ }^{88}$ Considering that the Talmud bans using police agent provocateurs, it is a rational rule to convict only one of the criminals in the case of bribery.

However, it should be noted that the Halacha made it a sin also to give a bribe but a sin that is not punishable by the human court but only by God. ${ }^{89}$ Maimonides determined, "[j]ust as the recipient transgresses a negative commandment; so, too, does the giver, as [Leviticus 19:14] states: 'Do not place a stumbling block before the blind."'90 This, of course, reduces the incentive of the bribe-giver to speak. However, the Halacha encourages the bribe-giver to speak: the bribe-giver may sue the bribe-taker to return the money. Maimonides determined, "'Do not take a bribe.' ... Such a person is included in the malediction, Deuteronomy 27:25: 'Cursed be he who takes a bribe.' He is required to return the bribe if he is demanded to by the giver." ${ }^{\text {"1 }}$ By giving the bribe-giver a right to sue the bribe-taker, the Jewish law gives the bribe-taker an incentive to expose the bribe-giver (which serves as a deterrent and cleans the legal system) but also makes a bribe part of civil law and excludes it from criminal law. This is so since in the Jewish law, "[w]henever a prohibition requires financial recompense, e.g., 'Do not rob,' or 'Do not steal,' it is not punishable by lashes."' ${ }^{\prime 2}$ By making it a part of civil law, the standard of proof is drastically reduced.

Furthermore, one may also interpret the Talmud such that we accept the testimony of the passive homosexual but not the testimony of the active homosexual. This would be even closer to the Talmudic law of bribery. The passive homosexual is seen as having the capacity to coerce the active homosexual through the passive homosexual's testimony. However, in this game, contrary to the Stag Hunt Game, neither of them has a legal incentive to be the first to testify.

${ }^{88}$ The Tora does not ban the giving of bribery: In The World of Charedim Blog (Feb. 16, 2015).

${ }^{89}$ See Moshe Ben Maimon, Sanhedrin veha'Onashin haMesurin lahem - Chapter 23, CHABAD, https://www.chabad.org/library/article_cdo/aid/1172746/jewish/Sanhedrin-vehaOnashin-haMesurin-lahem-Chapter-23.htm (last visited Jan. 21, 2021).

${ }^{90} \mathrm{Id}$.

${ }^{91} I d$.

${ }^{92}$ Moshe Ben Maimon, Sanhedrin veha'Onashin haMesurin lahem - Chapter 18, CHABAD, https://www.chabad.org/library/article_cdo/aid/1172741/jewish/Sanhedrin-vehaOnashin-haMesurin-lahem-Chapter-18.htm (last visited Jan. 21, 2021). 


\section{B. The Last is Responsible - The Talmudic Backward Induction}

We argue that there is a strong attitude in the Talmud that chooses to impose responsibility only on one of the criminals and that game theory can explain this attitude. We will give another example:

The rabbis taught: If ten different persons assaulted one, no matter whether at once or at other times and was killed, none of them has to suffer capital punishment, as according to the Scripture it must be known who was the cause of the death. R. Jehudah $b$. Bathyra, however, holds: In case the assault was made by one after the other, the last one is guilty, for he hastened his death. ${ }^{93}$

We will analyze what game is created by the rule of Rabbi Judah $b$. Bathyra; namely, the last is responsible. The game is such that each player has a strong incentive to not be the previous "beater." Therefore, the last potential beater will decide not to beat; the former potential beater will also choose not to beat; their former potential beater will also decide not to beat; and therefore, no potential beater will beat. We propose this simple model: there are "n" players, each of them chooses whether or not to hit, and each of them knows that the rule is that the last hitter, and only the last hitter, will be punished heavily. Therefore, the " $n$ " player will choose not to hit; the " $n-1$ " player can know this (and hence know it), and will, therefore, decide not to hit; the " $n-2$ " player can know this and will, therefore, not hit... the first player can understand this and will, therefore, not hit. This mainly prevents conspiracies of striking.

We argue: Rabbi Judah b. Bathyra actually chooses the minimal number of punished people who are sufficient to prevent the crime. This proposed rule may be justified by this argument: given that punishment is not costless, this rule is the cheapest way to prevent the crime!

Furthermore, one of the disadvantages of punishing more than one person is that it creates an incentive to remain silent. In the game created by Rabbi Judah, every player has an incentive to testify against the players who strike after them (meaning that player n-1 knows that the player $\mathrm{n}$ will testify against him. Another disadvantage of

${ }^{93}$ Babylonian Talmud, Sanhedrin 78a. 
punishing more than one person is that it may neutralize some people from being potential witnesses, particularly since, in Jewish law, an evil person cannot be a witness. Conversely, the traditional approach in Jewish law is that no more than one man will be punished in the case of the murder of one man. ${ }^{94}$ The approach of Rabbi Yehuda chooses the optimal rule given this limitation. In the simultaneous game, no one will be punished under Rabbi Judah's approach. However, not every criminal can know ex ante if it is a simultaneous game. No one wishes to be the last to stop hitting, to be the one who hastened his death. Even if the two players can communicate to end their hitting

${ }^{94}$ There are some Jewish scholars who resist this tradition. 


\author{
simultaneously, mutual mistrust can prevent this, ${ }^{95}$ such as in the Stag \\ Hunt Game. ${ }^{96}$
}

${ }^{95}$ Rabbi Moshe Ben Maimon, Rotzeach uShmirat Nefesh - Chapter 4, SEFARIA, https://www.chabad.org/library/article cdo/aid/1088920/jewish/Rotzeach-uShmirat-Nefesh-Chapter-Four.htm (Last visited Jan. 21, 2021).

It should be noted that the view of the majority that all beaters are exempted from punishment was reinterpreted by later sources. The Talmud interpreted it such that this opinion discusses only a case in which the first strike does have a potential to kill, and then we cannot determine who is responsible for the death, and because of this uncertainty, all of them should be exempted from punishment. But if the first strike has no potential to kill, the majority, according to the Talmudic interpretation, admits that the last is responsible since, then, the last causes the victim to lose his or her life.

A tanna recited before $\mathrm{R}$. Shesheth: And he that killeth all life of man: this includes one who smote his fellow, but there was not in his blow enough [force] to kill, and then a second came and killed him, [teaching] the latter is executed - But if the first man's blow was insufficient to kill, is it not obvious [that the second is liable]? - But [say thus: the first smote him] with sufficient force to kill, [but before he expired] a second came and slew him; then the second is liable.

Babylonian Talmud: Tractate Sanhedrin, HALAKHAH, http://www.halakhah.com/sanhedrin/sanhedrin_78.html (last visited Feb. 9, 2021).

This anonymous Baraitha (an external Mishna that was excluded from the canon by the editor of the Mishna but got attention by the Talmud) agrees with R. Judah b. Bathyra. Rambam, CHABAD, https://www.chabad.org/dailystudy/rambam.asp? $\mathrm{tDate}=3 / 25 / 2021$ \&rambamChapters $=3$ (last visited Feb. 9, 2021) ("Ten people threw stones at a person one after the other, and none of the stones was of sufficient weight to cause death. Afterwards, another person cast a stone that was of sufficient weight to cause death and the victim died. The last person who threw the stone should be executed."). This is also an indication that Maimonides rejects the view of R. Judah: "If ten people strike a person with ten different sticks and he dies, they are all not held liable for execution by the court. This law applies regardless of whether they struck him one after the other or they struck him at the same time." Rotzeach uShmirat Nefesh-Chapter, supra note 91.

${ }^{96}$ Interestingly, we have a model of strategic enforcement in the literature that recommends punishing those who make the most acute crime:

Consider a standard rule that sets cars' speed limit at fifty-five miles per hour. To implement this rule, police dispatch radar-equipped patrols to highways. The patrolling officers cannot stop every speeding vehicle. Instead, they stop only those cars whose speed is conspicuously above the limit. The "conspicuously above" criterion varies from one case to another: a speeding driver sometimes becomes conspicuous by exceeding the limit by ten miles, while in other cases the going rate is seventy-five miles per hour. Either way, the police keep their "conspicuously above" criterion unannounced. 
Interestingly, we have a similar discussion in the Talmudic Tort Law. ${ }^{97}$ When five persons sit on a bench, and it does not break, and another one comes and sits down, and it breaks, the last one is responsible (for the whole damage).$^{98}$

In this case, similar to the former, Jewish law imposes liability on the last person's liability to sit on the bench. What incentive is created by this game? Similarly, the person is incentivized not to act negligently; this incentivizes his or her former not to act negligently; what incentivizes his or her former not to act negligently, and this incentivizes everyone not to act negligently. ${ }^{99}$

We can also find a parallel discussion regarding prizes. ${ }^{100}$ There is a question, who will get the credit for making a mitzvah, a good deed that was begun by one and was finished by another? Let us see what Rashi, the most important commentator of the Bible, said following Midrash Tanchuma:

If you have started a mitzvah, finish it, because it is attributed only to the one who completes it, as it is said, "And the bones of Joseph, which the children of Israel had brought up from Egypt, they buried in Shechem". [Joshua 24:32]. But did not Moses alone occupy

\begin{abstract}
Drivers exceeding the speed limit consequently become motivated not to drive their cars conspicuously fast. When the speed of sixty miles per hour makes a driver conspicuous relative to other drivers on the same road, the driver will drive her car below that speed. The benefit from not being an outlier will motivate every driver to slow down. This speed-reduction process will stop at a point at which the driver becomes confident about other drivers' prevalent speed. This point can be set at sixty-five, sixty, or even fifty-five miles per hour and may depend on the traffic conditions, the police patrols' visibility, or on an individual driver's ability to count on other drivers' speed. The drivers' collective speed reduction will likely be significant. Most important, this social benefit will be achieved at an affordable cost.
\end{abstract}

Margaret H. Lemos \& Alex Stein, Strategic Enforcement, 95 MinN. L. ReV. 9, 9-10 (2010) (providing a model that does not recommend creating deterrence by punishing the last criminal but by punishing the most dangerous criminals; the application for a joint crime is that the heaviest criminal will be punished).

97 See Bava Kama 10b, SEFARIA, https://www.sefaria.org/Bava_Kamma.10b?lang=bi (last visited Apr. 12, 2021).

${ }^{98} I d$.

${ }^{99}$ However, this Mishna was reinterpreted by the Talmud.

100 See Can We Please Finish the Job?, ChABAD, https://www.chabadgreenwich.org/templates/blog/post.asp?aid $=2197590 \&$ PostID $=99654 \& \mathrm{p}=1$ (last visited Jan. 21, 2021). 
himself with them to bring them up? [See Exod. 13:19.] However, since he did not complete the mitzvah [of burying the bones], and [the children of] Israel did, [this mitzvah] is accredited to their name. ${ }^{101}$

We can see that Rashi said that, in the case in which one begins the mitzvah, and another finishes it, the credit for the mitzvah will go to the last one. Rashi presents this rule as an incentive to the one who began the mitzvah - if you do not finish it, you will lose all your credit. We can add that if the beginner stops making the mitzvah, then this rule incentivizes another person to complete it. The incentivizing of the other to complete the mitzvah incentivizes the beginner not to stop the mitzvah and additionally incentivizes the completeness of the mitzvah in the case that the beginner stops. Of course, this rule has a price: if the first one knows that he or she cannot complete it, he or she will not begin it. Maybe the rabbis prefer this since the same midrash in Tanchuma threatens that if people begin a mitzvah and do not complete it, they will be punished ${ }^{102}$. However, the alternative of giving the credit to the first one will not solve the problem, since in this case, the commandment is not completed, and thus, the first will not begin making the mitzvah.

Parallel to the opinion that the last, and only the last, will be punished in the case of a joint crime, this rule also provides that the last, and only the last, will get the credit in the case of a mitzvah. Jewish law sees considerations of incentives, and we propose additional incentive consideration; but it may be considered strange to argue that Rabbis may think that believers see consideration of incentives with their relationship with God? The readers may be surprised, but not only that this is the case, but that the Mishna (Avot 2) orders the believers to take the following considerations: "Consider the cost of a mitzvah against its rewards, and the rewards of a transgression against its cost." 103 We can see an example of this economic calculation in the Talmud:

Elazar ben Matya says: If my father says: Give me water, and there is a mitzva for me to perform at the same

\footnotetext{
${ }^{101} \mathrm{Id}$.

${ }^{102} I d$.

${ }^{103}$ Ethics of Fathers: Chapter Two, CHABAD, https://www.chabad.org/library/article_cdo/aid/2011/jewish/Chapter-Two.htm (last visited Apr. 12, 2021).
} 
time, I set aside the honor of my father and perform the mitzva, as my father and I are both obligated in the mitzva. Isi ben Yehuda says: If it is possible for this mitzva to be performed by others, let it be performed by others, and he should go and attend to the honor due to his father, as the honor of his father is his obligation alone. Rav Mattana says: The halakha with regard to this matter is in accordance with the opinion of Isi bar Yehuda. ${ }^{104}$

This means that the Talmud prioritizes mitzvahs according to considerations of efficient distribution of the work; the most important criterion is if the mitzvah can be performed by others.

\section{The Talmudic Principle-Agent Problem}

We will exhibit another example to our claim that there is a stream in the Talmud that imposes the responsibility on one side and only on one side. We will present the following Talmudic rule regarding the division of responsibility between the manager and the agent; that is, the rule's jurisprudential reasoning and, after this, some initial game-theoretical thoughts about the incentives that are given by this rule.

According to the Talmud, "a person's agent is like that of himself." 105 However, there is a rule that "there is no agent for wrongdoing," 106 which means that the agent, and only the agent, is responsible.

This rule, which is the dominant opinion in the Talmud, is applicable to both criminal law and torts, with the exception of the case of a holy trustee. ${ }^{107}$ The rule says that when the deed is forbidden, only the agent is responsible. ${ }^{108}$ Let us see a Talmudic example:

\footnotetext{
104 Babylonian Talmud: Kiddushin 32a, SEFARIA, https://www.sefaria.org/Kiddushin.32a?lang=bi (last visited Jan. 22, 2021).

105 Babylonian Talmud: Kiddushin 4lb, SEFARIA, https://www.sefaria.org/Kiddushin.41b?lang=bi (last visited Jan. 22, 2021).

106 Kiddushin 4la-82b, HALAKHAH 6, https://halakhah.com/rst/nashim/30b\%20\%20Kiddushin\%2041a-82b.pdf (last visited Jan. 21, 2021).

${ }^{107}$ See id.

${ }^{108}$ See id. at 7.
} 
He who sends forth a conflagration by a deaf-mute, idiot, or minor, is not liable [for the damage caused] by law of man, yet liable by the law of Heaven. But if he sends it by a normal person, the latter is [legally] liable. Yet why so? Let us say that a man's agent is as himself. - There it is different, for there is no agent for wrongdoing. ${ }^{109}$

The reasoning of the Talmud is similar to Kelsen's theory: 110 "[When] the words of the master and the words of the pupil are in conflict, whose are obeyed?"111 This means that the agent should obey God, and not the manager/sender. The pupil (the manager's rule) cannot contradict the rule of the master (God). We will translate it into the language of modern legal thought: the lower norm of the sender/manager cannot contradict the upper norm of God and therefore becomes void.

The main reasoning of the Talmud is a jurisprudential one, not an "economical" one. However, after this, the Talmud scholar, Raba, said that even Shamai, the (ancient) Rabbi who thought that the manager is also responsible in criminal law, will agree "that if one says to his agent, 'Go forth and have incestuous Intercourse,' [or] 'eat heleb' (nonkosher food - U.W.), the latter is liable and his sender exempt, because we never find in the whole Torah that while one derives pleasure [from wrongdoing] another is liable."112 Contrary to the theory of Gary Becker, which states that the expected punishment should be a function of social damage ${ }^{113}$, we should ask who enjoys the sin according to Rabba ${ }^{114}$.

\footnotetext{
${ }^{109} I d$. at 6 (alteration in original).

${ }^{110}$ See Hans Kelsen, Pure Theory of Law, The-Its Method and Fundamental Concepts, 50 L.Q. REV. 474, 481-81 (1934); Hans Kelsen, The Pure Theory of Law and Analytical Jurisprudence, 55 HARV. L. ReV. 44, 45 (1941); HANS KELSEN, GENERAL THEORY OF NORMS 123 (Clarnedon Press Oxford ed., 1990).

${ }^{111}$ Kiddushin 4la-82b, supra note 101, at 7; see Daf Shevui to Kiddushin 42b:10, SEFARIA, https://www.sefaria.org/Daf_Shevui_to_Kiddushin.42b.9?lang=bi ("There is no agency when one commits a wrongdoing. It may be wrong or careless for me to send someone else out with a dangerous substance which might cause damage, but I am not legally liable if he does so. He should have listened to the words of the master, i.e. God, who would prohibit engaging in damaging activities."). 112 Kiddushin 43a.

113 Gary S. Becker, Crime and Punishment: An Economic Approach, 76 J. PoL. ECON. 169, 181 (1968).

${ }^{114}$ Kiddushin 43a.
} 
Rabba spoke about an extreme case in which the sinner does not enjoy the sin and determined that the sinner will not be punished ${ }^{115}$. We can attempt to justify him by this argument: if there is no benefit for the sinner, we should not have a counter incentive. In the Talmud, "the presumption is that a man will not commit a sin unless he stands to profit by it himself," "116 which is actually a presumption of rationality. Rabba's extreme case raises the question of whether the regular rule should be that the punishment is a function of the benefit? We can say, in order to prevent the crime, it is sufficient that it will be nonpreferred by the potential criminal to commit it; and if the (expected) punishment is a little bit greater than the (expected) benefit, it is enough.

Let us go back to the rule that (only) the agent is responsible. It is a good question what incentives this rule provides. Since the agent who knows he or she will bear the punishment/compensation, the agent is incentivized to refuse to fulfill the mission. This is so, particularly because in Jewish law, there is a limitation on the capacity to punish as provided in the rule that no more than one person will be executed for the murdering of another one person ${ }^{117}$. While in modern tort law, the agent knows that he or she will not pay the full damage, however, in the Talmudic law, he or she will pay. Of course, the price of this rule is that the manager will pay nothing, except in very particular cases. Therefore, it seems that the incentive of the manager to command about wrongdoing is much greater in the Talmudic law than in modern law.

However, first, if the legal incentive of the agent to refuse to perform the manager's command is big enough, then the agent will not obey, and the agent who knows this will not command. Of course, the manager may pay more to the agent in order to make the legal incentive insufficient to prevent the wrongdoing.

Second, imposing liability on the manager gives validity to the manager's words. When one pays a price for his or her words, his or her words become more significant. For example, when the punishment for the threat itself is bigger, then the threat becomes more credible. ${ }^{118}$ When the agent knows that the manager pays for the manager's

${ }^{115} \mathrm{Id}$.

116 Babylonian Talmud: Tractate Baba Mezi'a 5b, HALAKHAH, https://halakhah.com/babamezia/babamezia_5.html (last visited Apr. 15, 2021).

117 "And if any mischief follow, then thou shalt give life for life" (Exodus 21-23, KJV).

${ }^{118}$ Uri Weiss, Discussion, The Robber Wants To Be Punished, The FEDERMAnN CENTER FOR THE STUdy OF RATIONALiTy, Hebrew U. of Jerusalem (2005). 
words, the agent knows that the manager is serious. One of the Halachic explanations for the rule that liberalizes the managers from liability is that we should not take their words seriously, that they (the manager) may say that they did not expect that the agent would obey. On this presumption, the Halacha actually (partially) deletes the manager's words. Those words do not exist in the world of the Halacha. When the manager pays for their command, it may cause an implicit threat not to do business with the refusing agent in the future a more credible one. For example, if the manager does not fire the agent who refuses to abide by his or her command, the manager may lose face. However, if there is no legal validity to the manager's words, then the manager may not lose face since the Talmud establishes a culture in which orders to commit wrongdoing should not be taken seriously.

Third, the manager and the agent can come to many kinds of agreements that compensate the agent as a function of the legal liability. Thus, let us examine from the point of view of Ronald Coase's theory. ${ }^{119}$ First, let us translate Coase's theory into the game-theoretical language (a language that is common, especially, in coalitional game theory). This is the translation we propose: the wrongdoing will be done if and only if the total benefit of the coalition of the manager and the sender from making the wrongdoing is bigger than the total cost of this coalition from committing the wrongdoing, including the transaction cost that is needed in order to create this coalition. In other words, the wrongdoing will be done if and only if the manager's benefit plus the agent's benefit is greater than the cost to the manager, plus the cost to the agent, plus the transaction costs needed in order to establish such transaction. This transaction has a particular kind of transaction cost created by the Talmudic law. The transaction between the sender and the agent is one that the Talmudic law does not recognize in its validity. By this rule, the Talmud increases the transaction costs. Furthermore, by imposing the full liability on the agent, the Talmud increases the transaction costs because if the manager pays in advance, the agent may not fulfill the mission. If the manager does not pay in advance, the agent likely knows that the agent cannot sue a manager. ${ }^{120}$

${ }^{119}$ Ronald H. Coase, The Problem of Social Cost, 3 J.L. \& ECON. 1, 87-137 (1960). ${ }^{120}$ To the best of my knowledge, there is no clear-cut law regarding the right of the agent to receive wages for the wrongdoing as "consented." To the best of my understanding, since it is not only prohibited, but void, the agent has no such right (this is the rule regarding interest or bribery). Mishne Torah: Mechirah, CHABAD, https://www.chabad.org/library/article_cdo/aid/1363981/jewish/Mechirah-Chapter- 
Furthermore, if it is right to interpret the Talmudic rule such that the manager will have the right to sue for the agent's money back (such as in the case of bribery or paying interest for a loan) ${ }^{121}$ because there is no legal validity for the wrongdoing, then the agent may be afraid that the manager will sue for the agent's money back, even if the agent is paid in advance. The agents should compensate the victim of the wrongdoing and give the money back to the manager. On the other hand, since the manager is a repeat player, maybe the repetition may replace the court. Aumann said in his Nobel lecture, "repetition is like an enforcement mechanism, which enables the emergence of cooperative outcomes in equilibrium - when everybody is acting in his own best interests." ${ }^{122}$ However, people do not wish to publish their wrongdoing, thus, the agent who does not get the money for the wrongdoing will not publish it. Therefore, this time the repetition cannot replace the court. However, if the manager wishes to continue doing business with the particular agent, the manager should pay the agent.

Fourth, another justification may be that the Talmudic law imposes the responsibility on the more risk-averse side and, in this way, makes the wrongdoing more expensive to commit.

Fifth, the division of responsibility may prevent the correction, the Teshuva. Let us assume that the agent dug a non-kosher pit. He can now prevent the danger by building a fence. The cost of the

Thirty.htm (last visited Jan. 22, 2021) (regarding illegal contracts, Maimonides explained that when a person sells or gives away property on the Sabbath - and needless to say, on the holidays - although he is punished by stripes, his deeds are binding). However, in this case, the deal is considered as having existed, but in the case of agency for wrongdoing, it is regarded as void. Another context in which the question regarding the duty to pay for a prohibited deed was raised by Rabbi Shlomo Avraham ben Aderet regarding the obligation to pay for prostitution, and he said that it is clear that the consented money must be paid since it belongs to the prostitute. See HAIM COHEN, THE LAW 788 (1991).

${ }^{121}$ Maimonides determined the following:

Although the lender and the borrower violate all the negative commandments mentioned above, they are not punished with lashes, because the interest must be returned. For whenever a person gives a loan at an interest, if fixed interest is involved, it is forbidden by Scriptural Law and may be expropriated through legal process. The judges expropriate it from the lender and return it to the borrower.

Moshe ben Maimon, Malveh veLoveh - Chapter 4, CHABAD, https://www.chabad.org/library/article_cdo/aid/1159441/jewish/MalvehveLoveh-Chapter-4.htm (last visited Jan. 22, 2021).

${ }^{122}$ War and Peace, supra note 40, at 17076. 
building is ten, and the expected damage is twelve. Similarly, as in the abovementioned example, if the rule is to divide the responsibility, then there is a prisoner's dilemma whether to build a fence:

Table 9.

\begin{tabular}{|l|l|l|}
\hline & Building a fence & Not Building a fence \\
\hline Building a fence & $-5,-5$ & $-10,0$ \\
\hline Not Building a fence & $0,-10$ & $-6,-6$ \\
\hline
\end{tabular}

However, we conclude that the Talmudic rule will lead the agent to build the fence. The idea of Teshuva is very dominant in Jewish thought, and the Talmudic division of responsibility between the agent and the principle incentivizes the Teshuva; it incentivizes the agent who dug a non-kosher pit to make it kosher. The example of digging a pit is one that the Talmud used in order to present this rule. ${ }^{123}$ More generally, the division of the responsibility discourages the adoption of the protective measure, given that only one person will bear the cost of adopting the protective measure.

Sixth, when the manager is free from responsibility, the manager may be incentivized to testify against the agent.

On the other hand, the challenge to the Talmudic rule is that a manager can send a bankrupt person. The Talmud actually discusses something similar, that the manager may send a child. ${ }^{124}$ The Talmud implicitly recognized that there is a problem in its rule and says that the manager is obliged according to the law of heaven, i.e. according to the law of God that cannot be enforced by court, but laws that a believer will obey (and if a member in the community does not obey those rules, the member may lose his or her reputation). ${ }^{125}$ One of the

\footnotetext{
${ }^{123}$ Bava Kamma 51a.

${ }^{124}$ Bava Kamma 59b The William Davidson Talmud.

125 Bava Kamma 59b, SEFARIA, https://www.sefaria.org/Bava_Kamma.59b.11?lang=en\&with=all\&lang2=en (last visited Apr. 17, 2021) ("One who sends a fire, i.e., places a burning object, in the hand of a deaf-mute, an imbecile, or a minor is exempt for any damage later caused by the fire according to human laws but liable according to the laws of Heaven".).
} 
commentators of the Talmud, Rabbi Asher Ben Jehiel (1250-1327), raised the possibility that in the case in which the agent has no money to pay, then the manager should pay according to the laws of heaven ${ }^{126}$. It should be remembered that the Talmudic law is a law of communities based on the assumption that the vast majority are believers and that this law is enforced mainly by the mechanism of reputation. Thus, we can study from the Talmudic law, but before adopting a Talmudic law, one should take into account the differences between a law of a community and a law of the state.

We have a parallel discussion about the rule that "there is no agent for a wrongdoing" 127 in Bava Metzia 10. One Talmudic scholar said,

Rabina answered: We say 'there is no agent for a sinful act' only when the agent is subject to the law prohibiting the act, but in regard to [a thief's] 'ground', which cannot be said to be subject to the law prohibiting the act [of stealing] the responsibility [does not lie with the agent, but it] lies with the originator [of the deed]. ${ }^{128}$

Later Rabbis, such as Rabbi Joseph Karo (1488-1575), the author of the most accepted Jewish halachic code (Shulchan Aruch), referred to this passage in the Talmud when he discussed the rule in the book in which he discussed the code (Beit Yoseph). Some of Karo's commentators, such as Rabbi Joshua Falk (1555-1614) extended this exception to the case of a bankrupt agent also, i.e., they impose responsibility on the sender, when the agent has no money to pay ${ }^{129}$. However, this law is controversial and vague: Rabbi Falk said that it seems to him that in this case, the sender will be responsible ${ }^{130}$. He actually extended the opinion of Rabbi Asher ${ }^{131}$ and explained that the agent should pay according to the law of heaven to possible obligation according to the laws of humans ${ }^{132}$.. My impression is that some later rabbis believed

\footnotetext{
${ }^{126}$ Kiddushin 42:2. Tosfot Rabbi Asher ben Jehiel.

${ }^{127}$ Kiddushin 4la-82b, supra note 101.

128 Babylonian Talmud: Tractate Baba Mezi'a, HALAKHAH, http://www.halakhah.com/babamezia/babamezia_10.html (last visited Apr. 17, 2021) (alteration in original).

${ }^{129}$ Rabbi Joshua Falk's comment on Choshen Mishpat 292, 4.

${ }^{130} \mathrm{Id}$.

${ }^{131}$ Kiddushin 42:2. Tosfot Rabbi Asher ben Jehiel.

${ }^{132}$ Rabbi Joshua Falk's comment on Choshen Mishpat 292, 4.
} 
that there was a problem with the case of a bankrupt agent and therefore reinterpreted the rule but thought that it is inconsistent with the internal logic of then Talmudic discussion, so they presented it as a possibility. ${ }^{133}$

Another exception that was determined by the Jewish literature is in the case of a commandment by a king. ${ }^{134}$ Rabbi David Kimchi (1160-1235), who was a leading commentator on the Bible, said that even though the agent should refuse the king's command, the vast majority would not do so, since they are afraid of the King, and thus the king should be punished for the wrongdoing of his agents. ${ }^{135}$

Those exceptions actually represent cases in which the rule will not be productive anymore. According to the legal logic, we should not have such exceptions, but later rabbis determined such exceptions.

\section{SUMMARY}

The Talmud is consistent in its imposition of responsibility on only one of the partners in crime, and this type of imposition makes conspiracy more dangerous for the criminal, thus improving deterrence against committing a crime. This is the Talmudic rule regarding bribery and criminal testimony in joint crime, and this is the opinion of Rabbi Jehudah b. Bathyra regarding a joint murder. ${ }^{136}$ This approach is also valid regarding torts and the division of the credits for a mitzvah.

\footnotetext{
133 Those rabbis actually extended the exception that an agent who is not subject to the law de jure does not give exemption to the sender (Rabina's opinion in the Talmud), as well as to cases in which the agent is not subject to law de facto.

${ }^{134}$ Aaron Kirschenbaum, A Cog in the Wheel: The Defence of "Obedience to Superior Orders” in Jewish Law, 4 ISRAEL Y.B. ON HuM. RTS. 168, 168-93 (1974).

135 Radak on II Samuel 12:9, SEFARIA, https://www.sefaria.org/Radak_on_II_Samuel?lang=bi (last visited Apr. 17, 2021).

${ }^{136}$ Sanhedrin $7 \overline{8}$.
} 